\title{
A Case Study Of Procurement Of Christian Education Teacher In Public Elementary School In Sub-District Of Candisari Of Semarang
}

\author{
Surja Permana \\ Institut Kristen Borneo \\ logos.surabaya@gmail.com
}

\begin{abstract}
Purpose : The purpose of this research was to know the reasons or causes of lack or absence of Christian Education teachers

Design/methodology/approach :The method used in this research was explorative-descriptive case study. Case study procedure in this research had four stages: description (observing/studying), analysis (trying to understand), interpretation (interpretation of data), and action (action plan based on the result of research data).

Findings : the main obstacle to procurement of $C$ hristian Education teachers as Non-Permanent Teachers was lack or absence of budget

Research limitations/implications : This study was limited to the number of Christian students. Interview means that the researcher asked questions to school administrators to obtain information according to research variables. To complete the information required, the researcher observed on the implementation of Christian Education at Public Elementary School in Subdistrict of Candisari, Semarang.

Practical implications :First, in Sub-district of Candisari there were 37 Public Elementary Schools. Thirty-six schools had Christian students. There were only six Christian Education teachers who teaching Christian Education at 16 schools. Six Christian Education teachers for 16 schools, mean $43 \%$ of schools had teachers who teaching Christian Education. That mean $57 \%$ or 20 Public Elementary Schools in Sub-district of Candisari had no Christian Education teachers.
\end{abstract}

Originality/value : the Government or the school administrators were less concerned with the implementation of Christian Education, then the church (Christian community) must be willing to assume the responsibility by sending and financing Christian Education teachers to schools that did not have Christian Education teachers yet

Paper type : Research paper

Keyword : Procurement, Christian Education Center, Candisari

A Case Study Of Procurement Of Christian Education Teacher In Public Elementary School In Sub-District Of Candisari Of Semarang

Surja Permana 


\section{INTRODUCTION}

The implementation of education in Indonesia, including religious education is governed by Laws and Government Regulations. Education is the right of every Indonesian citizen guaranteed and governed by Law. In the Preamble of the Constitution of 1945stated that one of the goals of Indonesia's independence is the intellectual life of the Nation of Indonesia. In the Constitution of 1945 Article 31 paragraph 1 is mentioned: "Every citizen shall be entitled to teaching."And in paragraph 2 it is mentioned: "The government shall undertake and organize a National Teaching System that is governed by Law." In People's Consultative Assembly (MPR) Decree No.11/MPR/1993 on Outlines of the State Policy it is mentioned: National education which is rooted in the culture of Indonesian Nation and based on Pancasila and the Constitution of 1945 directed to increase intelligence and dignity of the Nation, manifesting people and people who believe(faithful) and devoted to God Almighty, qualified, independent so as to build himself and the surrounding community and can fulfill the needs of National development and responsible for Nation building (Nasution, 1988).

The implementation of education is regulated in the National Education System Act. Indeed the new National Education System is composed entirely at the beginning ofFive-Year Development (Pelita) $V$ which is the result of the Government agreementand Parliamentendorsed by President Suharto as Law No. 2 of 1989. (Ruwiyanto, 1977). Law Number 2 of 1989and MPR Decree No.11/MPR/1993 shows Indonesian Nation to pay attention to education, as in the following example:The Government is very concerned about education within our country in order to educate the Nation's life. So,someone is accepted to be a learner and organized by not discriminating gender, religion, social position, economic ability level (Article 7 of Education Law No.2, 1989). The

A Case Study Of Procurement Of Christian Education Teacher In Public Elementary School In Sub-District Of Candisari Of Semarang

Surja Permana 
right of every Indonesian citizen to obtain an education has a strong legal basis and binding. Therefore, any party is not allowed to obstruct the person's intent to learn and to getteaching.

The implementation of Law No. 2 of 1989 initially did not cause problems. The Law referred to in Article 28, paragraph 2 stated that religious Education teachersshould be religious in accordance with the religion taught to the learners concerned. After Indonesia entered the reform era, the implementation of Law became problematic with the issuance of Joint Decree of Minister of Religious Affairs and Minister of Education and Culture No.4/U/SKB/1999 signed by Minister Malik Fajar and Minister Juwono B. Sudarsono. The Minister'sJointDecree was followed up by the issuance of Decree of the Directorate General of Elementary and Secondary Education No.64/C/Kep/PP/2000 regulating the students are obliged to follow religious lessons according to the religion of the students.

In the next journey, Law of National Education System, especially the implementation of religious education at school cause problem. The emergence of Law No.20 of 2003 on National Education System also raises pros and cons. In Article 12 paragraph 1a mentioned that every learner in each educational unit is entitled to religious education in accordance with the religion that is adhered and taught by educators who same faith. It becomes a problem for public schools because few students make Christian Education at schools less attention from the Government.

The impact of the contents of Article 12 was extremely felt in Public Elementary School in Sub-district of Candisari of Semarang. At these schools were found a number of the following facts. In every school, the number of Christian Studentswere the least. As a result, the school was less concerned about the implementation of Christian Education for them. This was proven by the non-availability of permanent classrooms, not always provided Christian

A Case Study Of Procurement Of Christian Education Teacher In Public Elementary School In Sub-District Of Candisari Of Semarang

Surja Permana 
Education teachersin every Public Elementary School, no salary budget for Christian Education teachers if there was teacherwho ready to teach Christian Education, the number of Christian Education teachers in this research were no more than 10 people of 37 Public Elementary Schools in Sub-district of Candisari, Semarang.

\section{Research Purposes}

The purpose of this research was to know the reasons or causes of lack or absence of Christian Education teachers, to find the prudent way so that in every Public Elementary School be Christian Education teacher, and stated very important role and function of Christian Education teachers of every Public Elementary School in Sub-district of Candisari.

\section{MATERIAL AND METHOD}

The method used in this research was explorative-descriptive case study. Case study procedure in this research had four stages: description (observing/studying), analysis (trying to understand), interpretation (interpretation of data), and action (action plan based on the result of research data).

Data collection was done by interview, document examination, and observation. The primarily examined document was the number of Christian students. Interview means that the researcher asked questions to school administrators to obtain information according to research variables. To complete the information required, the researcher observed on the implementation of Christian Education at Public Elementary School in Subdistrict of Candisari, Semarang.

A Case Study Of Procurement Of Christian Education Teacher In Public Elementary School In Sub-District Of Candisari Of Semarang

Surja Permana 


\section{National Education of Indonesia}

Actually, educational activities have been going on since time immemorial, since human was createdand human life begins. Process and education system continue to develop according to the demands and global changes so that the goal of education is the increase of human resources (Human Resource Development) can be achieved. Thiscase also occurs in National Education of Indonesia.Husain (1995) said that National education serves to develop capabilitiesand to improve the quality of education and human dignity of Indonesia in order/efforts to realize the National goals. ThePreamble of the Constitution of 1945 paragraph 4 giving an emphasis that Indonesia's national goal is to protect the entire Indonesian Nationand the entire Indonesian blood spill; promoting public welfare;the intellectual life of the Nation; and participating the implementation of world order.

With the intention of improving the quality of education then made the National Education System of Indonesia. The latest National Education System is the Law of the Republic of Indonesia Number 20 of 2003. In the Law, the vision of Indonesian education is the realization of the National Education System as a strong social order and authoritative to empower all Indonesian citizens to develop into qualified human beings so as to be proactive in responding to the challenge of changing Nation. The visionswere elaborated in the following five missions:

1. Striving the expansion and equality of opportunities to obtain quality education for all Indonesians.

2. Assisting and facilitate the development of the Nation as a whole since early to the end of life in order to realize the learning community.

3. Increasing the readiness and the quality of educational process to optimize the formation of moral personality.

4. Improving professionalism and accountability of educational institutions as

A Case Study Of Procurement Of Christian Education Teacher In Public Elementary School In Sub-District Of Candisari Of Semarang

Surja Permana 
knowledge culturalcenter, skills, experiences, attitudes, and values based on National and Global standards.

5. Empower community participation in the implementation of education based on the principles of autonomy and the context of the Unitary State of the Republic of Indonesia.

\section{Government Regulation Number 55 of 2007 on Religious Education}

Religious education is education that provides knowledge and shapingattitudes, personality, and skills of learners in practice their religious teachings, thatheld at least through the subjects on all paths, levels and types of education. In article 2, paragraph 1 mentioned thatReligious Education serves to form faithful Indonesian people and devoted to God Almighty and has noble character and able to maintain peace and harmony between inter-religious and inter-religious relationships.

The Government Regulation regulates the implementation of religious education in schools. In article 3, paragraph 1 mentioned: "Each educational unit on all paths, levels and types of education must carry out religious education".And in article 4, paragraph 2 mentioned:Every learner in educational unit on all paths, levels, and types of education are entitled to religious education in accordance with the religion adhered to and taught by educators who have same faith.

In public schools the procurement of Christianityteachers should be the Government obligation as set forth in Article 6 paragraph 1 that educators of religious education in educational units organized by the Government or regionalgovernment are provided by the Government or regional government according to the respective authorities based on Legislation Regulations. But the facts in various public schools show that many schools have Christian students but do not have Christian Education teachers. It should be a concern

A Case Study Of Procurement Of Christian Education Teacher In Public Elementary School In Sub-District Of Candisari Of Semarang

Surja Permana 
and championed by Christians in Indonesia, do not get Christian Educationat school abolished because there is no Christian Educationteacher, no budget, and various other obstacles.

Pay attention to all the legislation as already outlined, it is clear that Christian Educationas part of religious education in schools is mandatory. Should every Christian student in Public School be entitled to Christian education, and the Government or school administrators are obliged to provide Christian Education teachers, budgets, and supporting facilities so that Christian Educationin schools is going well to achieve National education goals. But it still needs to be fought, because in many public schools that have Christian students it does not have Christian Education teachers either permanent status teachers or of non-permanent status teachers. The procurement of Christian Education teachers in schools still needs to be pursued so that Christian Educationin schools can still take place well.

\section{Christian Education at Elementary School Level}

Parenting, raising and educating of children are the noble task that should be done by parents and educators withappropriate manner in accordance with the physical developmentand children's psychology. Children have different special characteristics than teenagers and adults. Therefore, Christian Educationfor children should be adjusted to the child's development.

In the Old Bible Testament, very central institution in education is the God's Temple and the synagogue. In the New Testament, it is church or congregation. The Bible states the importance of Christian Educationboth at home, church,and schools like some of the following Bible verses:

Deuteronomy 6:4-9 "...you shall teach it repeatedly to your children... wherever... when you sit, lay down, and..."

Ephesians $6: 4$ "...educate them in doctrine and exhortation of God".

A Case Study Of Procurement Of Christian Education Teacher In Public Elementary School In Sub-District Of Candisari Of Semarang

Surja Permana 
II Timothy 3:16, Scripture is useful for "teaching, declaring wrongs, correcting behavior, and educating in righteousness".

Proverbs 22:6 "educate the young person in the way he deserves, then in his old age he will not depart from that way".

Christian Educationstudents are expected to be disciples who are faithful, obedientand faithful to do the word of God, noble characterand virtuous noble character whichare reflected in personal life, society, Nation and State; liveand practicing the teachings of Christianity, respectingothers despite different religionsand being able to live in harmony.In particular at the ElementarySchool level there are four competencies that are expected, namely:

1. Understanding God's love through the existence of himself

2. Responding to God's love by loving parents, family, and friends

3. Worship to God as a thanksgiving through prayer and Bible reading

4. Maintaining the other creations of God in everyday life

Christian Education is not only important in the Church, but in accordance with the opportunities given in Indonesian National Education System, Christian Education becomes very important in schools. In the early centuries and in the present Christian Education is very important because God wants it. Enns (2004) briefly mentioned the benefits of Christian Education as follows :The instruction is a vital element in the life of the early church. God gave Holy Scripture in order to teach the congregation and lead them to adulthood (2 Timothy 3:16-17). Teaching is an antidote against false doctrine (1 Tim.1:3);teaching produces love among the believers (1 Tim. 1:5);produce a healthy spiritual diet (1 Tim. 4:6); righteousness (1 Tim. 4:6-16); obedience (1 Tim. 5:17, 6:2); and the proper focus of someone's life (1 Tim. 6:17).Paul gave instructions to Timothy to teach others in order to grow (2 Tim. 2:2; see 1 Tim. $4: 14,16 ; 6: 20)$.

The interests of Christian Education for children are reflected in the

A Case Study Of Procurement Of Christian Education Teacher In Public Elementary School In Sub-District Of Candisari Of Semarang

Surja Permana 
Volume 1 Number 12017

This work is licensed under a Creative Commons Attribution-

following poem:

If a child is raised with reproach,

He learns to cussing

If a child is raised with hostility,

He learns to fight

If a child is raised with scorn,

He learns to be inferior

If a child is raised with humiliation,

He learns to always love himself

If a child is raised with tolerance,

He learns to refrain

If a child is raised with full support,

He learns to be confident

If a child is raised with praise,

He learns to appreciate

If a child is raised with good treatment,

He learns to be fair

If a child is raised with a sense of security,

He learns to hasconfidence

If a child is raised in full recognition,

He learns to love himself

If a child is raised with honesty,

He learns the truth

If a child is raised with acceptance and friendship,

He learns to determine affection

If a child is raised with affection,

He learns to find love in his life.(Nolte, 1982)

A Case Study Of Procurement Of Christian Education Teacher In Public Elementary School In Sub-District Of Candisari Of Semarang

Surja Permana 
Meier (1983) said that about $85 \%$ of an adult's personality has been formed at the time he reaches the age of 6 years. The remaining $15 \%$ polish the child to shape him/her into a good Christian teenager. In the age between 6 to 18 years happentusslepsychological and spiritual. Therefore, the best for children is to get discipline, education and affection.

The estuary of children's Christian Education is the children live in the love of God. Meaning that children experience the love of God, the children learn to love God, love themselves healthily, love others sincerely, and love other creations of God. In other words, Christian Education should be able to answer the children's needs, the need to be accepted and possessed, the need to feel successful, the need to be free from fear, the need to receive affection, the need to be free from guilt, the need to contribute, the need to understand and knowledgeable, as well as the need to feel secure.(Smith, 1999)

In Indonesian National Education System there is a wide opportunity to teach Christian Education at school. That opportunity should be exploited as well as possible, because the children are in school from Monday to Saturday, six days a week, and Christian Education lessons can be done systematically and regularly. According to Homrighausen (2009) there are four benefits of Christian Education in public schools, as follows:

1. In this way, the church can convey the Gospel to many children who are difficult gathered in Christian Education of church own.

2. Children who get Christian Education at school, will feel that general education and religion are not two things that have no relationship, but instead had to walk together. Christian Educationhas its place in the field of general education environment. God and the Christian church are closely

A Case Study Of Procurement Of Christian Education Teacher In Public Elementary School In Sub-District Of Candisari Of Semarang

Surja Permana 
related to lifeand science of human beings generally.

3. Moreover, if the church unable to pay for Sunday School work, then Christian Educationin public schools help the weakened church financially.

4. And finally, there is the benefit that with the inclusion of religious teachings in the general lesson plan, then religion itself by itself begins as an absolute part of the culture of the whole people. Those schools aim to educate children to become responsible citizens.

\section{RESULT AND DISCUSSION}

After doing the research process, then obtained the following conclusion:

First, in Sub-district of Candisari there were 37 Public Elementary Schools. Thirty-six schools had Christian students. There were only six Christian Education teachers who teaching Christian Education at 16 schools. Six Christian Education teachers for 16 schools, mean $43 \%$ of schools had teachers who teaching Christian Education. That mean $57 \%$ or 20 Public Elementary Schools in Sub-district of Candisari had no Christian Education teachers.

Second, the implementation of Christian Education at Public Elementary School in Sub-district of Candisari was still far from expectations. In fact, there were 20 Public Elementary Schools that did not have Christian Education teachers.

Third, in those 20 schools, surely Christian students did not get Christian Education as they should. During religion classes, Christian students were free activities and playing.

Fourth, the main obstacle to procurement of Christian Education

A Case Study Of Procurement Of Christian Education Teacher In Public Elementary School In Sub-District Of Candisari Of Semarang

Surja Permana 
Volume 1 Number 12017

This work is licensed under a Creative Commons Attribution-

ShareAlike 4.0 International License.

teachers as Non-Permanent Teachers was lack or absence of budget. Whereas, the availability of Christian Education teachers was the main thing for the implementation of Christian Education regularly and planned, and the achievement of Christian Education goals for Christians students. So, the procurement of Christian Education teachers was urgent and should be done immediately.

Fifth, because the Government or the school administrators were less concerned with the implementation of Christian Education, then the church (Christian community) must be willing to assume the responsibility by sending and financing Christian Education teachers to schools that did not have Christian Education teachers yet.

\section{REFERENCES}

Enns, Paul, The Moody Handbook of Theology: Buku Pegangan Teologi (Malang: Literatur SAAT, 2004).

Homrighausen dan Enklaar, Pendidikan Agama Kristen, 2009.

Husain, Abdul Rajak, Penyelengaraan Sistem Pendidikan Nasional (Solo: CV. Aneka, 1995).

Hutabarat, Pedoman Untuk Guru PAK, (Semarang: STBI, 2005).

Nasution, Azas-Azas Kurikulum (Bandung: Jemmars, 1988), hlm. 62-66.

Nolte, Dorothy Low 1982 seperti dikutip oleh Hilda Karli, Head-Hand-Heart: 3 H Dalam Kurikulum Berbasis Kompetensi (Bandung: Bina Media Informasi, 2007).

Meier, Paul D. Membesarkan Anak dan Perkembangan Watak Secara Kristen (Surabaya: Yakin, 1983).

A Case Study Of Procurement Of Christian Education Teacher In Public Elementary School In Sub-District Of Candisari Of Semarang

Surja Permana 
Volume 1 Number 12017

This work is licensed under a Creative Commons Attribution-

Ruwiyanto,Wahyudi. Manajemen Sisdiknas Dalam Rangka Peningkatan Ketahanan Nasional (Jakarta: Balai Pustaka, 1997).

Singgih G. Gunarso, Psikologi Perkembangan Anak dan Remaja (Jakarta: BPK Gunung Mulia, 1986).

Smith, Daniel H. Bawalah Anak-Anak Kepada Yesus (Bandung: Lembaga Literatur Baptis, 1999).

Wiriadinata, Eddy J. dan Susan S. Wiriadinata, PAK Anak-Anak Bagi Pelayanan Gereja (Semarang: STBI, 2002). 